Горбач Наталя,

кандидат філолологічни наук, доцент, завідувач кафедри української літератури Запорізький національний університет

\title{
ГУМАНІСТИЧНІ ВИМІРИ ЗБІРКИ Й. БУРГА «ПІСНЯ НАД ПІСНЯМИ»
}

\begin{abstract}
Стаття присвячена гуманістичним виявам у прозовій збіриі «Пісня над піснями» ідишомовного письменника України Й. Бурга. Вони аналізуються крізь призму художнього осмислення соиіально-побутових, релігійних, культурних, політичних, історичних реалій життя євреїв XX ст. у складі різних державних утворень. Предметом окремої уваги стає тема Голокосту як иентральна сюжетотворча тема збірки.
\end{abstract}

Ключові слова: національна культура, картина світу, гуманістичні вияви,топос, локус, Голокост.

\section{Humanistic features of collection «The Song of All Songs» by J. Burg.}

The article is dedicated to humanistic features of prose anthology "The Song of All Songs» by J. Burg, the Ukrainian author who wrote in other language. They are analyzed through the prism of artistic comprehension of social, religious, cultural, political, historical realities of Jewish life in the XX ct. in different states. The subject of a particular attention is the Holocaust theme as a main theme of the anthology which forms the plot.

Keywords: national culture, the image of world, humanistic features, topos, locus, Holocaust.

Йосифа Бурга (1912-2009) називали людиною-легендою, літописцем і хроністом єврейського життя, класиком, патріархом єврейської літератури. Сьогодні творчість письменника знана у світі, бо його доробок перекладався німецькою, російською, польською, італійською та іншими європейськими мовами, відзначений кількома престижними літературними преміями. Але передусім він, за висловом П. Рихла, був «останнім лищзарем ідищу не тільки на пострадянському просторі, але й загалом у всій Свропі» [Рихло 2012 :12].

У перекладі українською мовою, крім кільканадцяти творів у періодиці, вийшли книги вибраної прози Й. Бурга «Два світи» (1997), «Квіти і сльози» (1997), «Розмаїті стежки» (1997) й «Пісня над піснями» (2012). Проте, об’єктом 
аналізу вітчизняного літературознавства твори малих жанрових форм автора ще не ставали.

Метою нашого дослідження $є$ етнонаціональні вияви в прозовій збірці «Пісня над піснями» Й. Бурга, зокрема, художнє осмислення письменником соціально-побутових, релігійних, культурних, політичних, історичних реалій життя євреїв XX ст., Голокосту як центральної сюжетотворчої теми збірки. Обраний аспект рецепції доробку Й. Бурга може отримати продовження як у контексті досліджень із літературної імагології, так і в студіюванні теми Голокосту в літературі.

На долю Й. Бурга випало чимало трагічних випробувань, але біль від втрати матері й брата в роки Голокосту, від 20-річного поневіряння в чужих краях - Поволжі, Узбекистані, Уралі, Москві - не витравили в серці письменника любові до рідної землі. Майже на передодні свого 90-річчя в інтерв”ю західнонімецькій газеті «Райтішер Меркур» він зізнався: «Коли я народився, Австрія вважалася нашою вітчизною, Відень - нашою столицею, а Франц Йосиф - нашим цүісарем. Коли я був підлітком, то нашою вітчизною стала Румунія, нашою столицею - Бухарест, а Фердінанд - нашим королем. Коли я дійшов зрілості, то наша вітчизна почала зватися Радянським Союзом, наша столиия - Москвою, а Сталін був батьком усіх народів. Але я не австрієць, не румун $і$ не росіянин, я - буковинецьь... Я буковинец̧ь від маківки до n’ят» [цит. за : Рихло 2012 : 5].

Про «Ноmo Bukowinensis» як представника пограничної регіональної спільноти, носія специфічного типу культури й філософії екзистенції говорять й автори монографії «Особливості буковинського пограниччя: історія культурного полілогу» [див. : Антошкіна 2010 : 28]. Мультикультуралізм та міжетнічний полілог населення Буковини відзначав i Й. Бург: «Tym завжди жили українці, євреї, румуни, поляки, угориі... До приходу радянської влади кожна етнічна меншина мала у Чернівцях свої духовні $і$ культурні цеентри, народні доми. I всі вони мали можливість для розвитку своєї культури. У нашому місті звучало розмаїття мов, схрещувалося багато культур. I вони не 
могли не впливати одна на одну. Саме буковинська земля дала світові відомих письменників: О. Кобилянську, П. Целана, М. Емінеску, Ю. Федьковича, Р. Ауслендер, Д. Загула, а також єврейських, які писали мовою ідиш: Е. Штейнбарга, М. Альтмана... Незважаючи на те, що з 1918 р. до 1940 р. Буковина належала Румунії, а потім СРСР, австрійська толерантність $і$ досі збереглася у взаєминах між етнічними меншинами регіону ...» [цит за : Вишневська 2012].

Підбірку творів Й. Бурга «Пісня над піснями», що в перекладі П. Рихла вийшла до 100-ліття від дня народження автора, відкриває оповідання «Скалки». Тут, за словами письменника, зібрані «далекі, незабутні враження дитинства» [Бург 2012 : 13], що набувають відчутних, зримих обрисів. Дитинство героя має географічні координати - це містечко Вижниця, «мальовничо розкидане в долині, біля самого підніжжя буковинських Карпат, де мешкало багато поколінь євреїв» [Бург 2012 : 14]. Напівголодні дитячі роки асоціюються передусім із двома порами року, що маркуються крізь призму фізіологічного механізму тамування голоду: літо як пора, коли «дозрівали яблука у попівському саду, а трохи далі, за християнським ивинтарем, росли нічийні сливи» [Бург 2012 : 13] і зима - «низка голодних днів» [Бург 2012 : 13]. Дитинство оповідача - це також і пам'ять про людей: i рідні, і далекі вони постають у вимірах їхньої професійної вартості, бо все життя були приречені тяжко працювати і жити з мізерних плодів своєї праці. «Трудились, як воли, щоб залишити потім ией світ у чужім савані» [Бург2012 : 14], - говорить герой про кілька поколінь своїх предків, що працювали плотогонами. А із захоплення талантом скромного місцевого майстра виростає любов хлопця до кравецької справи: «якраз Мойдл-кравець винен у тому, що через кілька років я також сидів за швейною машинкою і на все життя зберіг любов до изього ремесла» [Бург 2012 : 19]. Особливою настроєвістю позначені й фрагменти, присвячені школі. Це і портрет ребе Хаїма Герша, що маючи в буденному житті «вигляд людини, гірко обманутої життям» [Бург 2012 : 22], при тлумаченні П’ятикнижжя набував одухотвореного вигляду, «ніби сам був присутнім при 
створенні світу» [Бург 2012 : 22]. I зроблені з видовбаного гарбуза ліхтарики, при світлі яких єврейська дітвора поверталася з хедера додому. I мрії про новий світ, позбавлений сліз і несправедливості.

Далі твори автора структуровані за чотирма розділами - «Серед віденських кам'яниць», «Під небом Буковини», «Російські враження», «Постаті». У назви трьох перших винесено топоси дії творів.

У розділі «Серед віденських кам’яниць» художній простір колишньої австрійської цісарської резиденції передається через протиставлення культурологічного образу, що закарбовувався у свідомості людей упродовж тривалого часу, і тієї картини міста, яка відкривається перед героєм у 1930-х роках. Поряд із Віднем як місцем розкішних палаців, барокових колонад, середньовічних готичних споруд, батьківщиною віденського вальсу, безсмертну славу якому приніс Йоган Штраус, постає австрійська столиця, у якій ростуть антисемітські настрої. Від уваги героя за віденською святковістю і безтурботністю не приховуються загрозливі знаки прийдешнього лихоліття. Ці знаки «прочитуються» ним у заголовках газет, «чорних павучих хрестах свастик» [Бург 2012 : 29], що чимдалі частіше 3'являлися на стінах віденських будинків. Тому судовий процес над французьким офіцером єврейського походження Альфредом Дрейфусом, що був сфабрикований ще 1894 року на хвилі антисемітських настроїв у Франції, але мав широкий світовий резонанс, бачиться авторові лише як «трагічна прелюдія до тридиятих років» [Бург 2012 : 29]. Згадка про цю судову справу постає в оповіданні у зв'язку 3 фільмом «Я звинувачую», що йшов тоді у віденських кінотеатрах. Йдеться про кінострічку німецького режисера В. Дітерле «Життя Еміля Золя» (1937). Назву «Я звинувачую» картина отримала в радянському прокаті за заголовком відкритого листа до президента Франції письменника Е. Золя, який картав владу країни за антисемітизм. Кінострічка, як і сам вчинок французького письменника, мали б слугувати доказом впливу інтелектуальної еліти на дії влади, суспільні настрої, можливості боротьби проти національної дискримінації i соціальної несправедливості, але Й. Бург змушений 
констатувати проминальність цього історичного досвіду. Найтрагічнішою в австрійській історії він називає весну 1938 року, коли «на західних кордонах Австрії світ семимильними кроками наближався до катастрофи» [Бург 2012 : 31]. Прихід «моторизованих орд варварів» приносить у Відень багаття 3 книжок, нацистські гасла екзальтованого натовпу і єврейське гетто в другому районі міста.

I для самого Й. Бурга як ідишомовного письменника, i для його персонажа в оповіданні «У сутінках», важливим моментом нараціїє питання мови. Герой саме ідиш вважає своєю рідною мовою, але повсякчас наштовхується на iï несприйняття навіть у єврейському студентському товаристві «Юдея», члени якого, як і все асимільоване єврейське населення, послуговуються німецькою. Упосліджене становище ідишу підкреслюється і зневажливим ревінням натовпу, що не бажає чути мови східноєвропейських євреїв, і такими знайомими для підневільних націй шовіністичними штампами на кшталт «Жаргон» чи «Iдим - зіпсуmа німецьька» [Бург 2012 : 29, 30]. Але особливістю художньої картини світу Й. Бурга є іiі «врівноваження»: зла добром, жорстокості - любов’ю, фанатизму - розсудливістю, невігластва мудрістю. Так є і в питанні мови, бо на другому художньому полюсі боротьби за неї - професор давньонімецької мови, від якого герой Й. Бурга чує таке бажане й водночас неочікуване в академічній установі: «Ідиш, молодий друже, изе самостійна мова» [Бург 2012 : 30], поет Мендель Нейгрешл, рядки якого для героя набувають змісту одкровення: «О дух живий, о дух обнови, / Постань зелом моєї мови. / Вогнем спахни у слові знов, / Збунтуй мою гарячу кров» [Бург $2012: 30]$.

За цим же законом «врівноваження», але вже волею перекладача й укладача збірки П. Рихла, поряд опиняються оповідання «Раса» і «Чужий», в яких порушено тему Голокосту. Героїв обох творів у особистісному плані об’єднує єврейське походження, а в суспільному те, що на житті кожного з них позначився аншлюс Австрії 1938 року. На цьому їхня подібність вичерпується. Бо перший - группенфюрер СС Отмар фон Вернер, проклинає кров своїх 
предків за те, що не зреклися свого єврейства раніше.«Проклятий єврей твій батько. Чому він не прийняв католицької віри до твого народження? Хто посмів би сьогодні чіпати твого внука?» [Бург 2012 : 38], - дорікає він покійному діду-генералу. Дивна смерть упродовж однієї ночі багатьох товаришів по службі наганяє на персонажа небезпідставний страх за власне життя. У Австрії, яка 1938 року ввійшла до Третього рейху, суспільство охоплене масовою істерією пошуку замаскованих євреїв і потомственний військовий Отмар фон Вернер усвідомлює свою участь. Автор майстерно змальовує психологічний стан людини, яка хапається за ефемерні шанси врятуватися від молоху нацизму, приходу якого посприяла сама, підтримавши аншлюс. Персонажеві то ввижаються службовці гестапо, які в архівах вишукують інформацію про його походження, то він намагається переконати себе в зовнішній несхожості на діда-генерала, портрет якого висить на стіні, чи сподівається дістати фальшиві документи, які б посвідчували його арійство в трьох поколіннях. Поштовий конверт, на якому не вказане нацистське звання адресата, ставить крапку в спробах Вернера врятуватися: він розуміє, що його заслуги перед рейхом нівелюються його походженням. Гірка іронія долі криється у фіналі твору: спотворене тіло Отмара фон Вернера, що наклав на себе руки, знаходять на тротуарі, на якому ще вчора лежали євреї, миючи сходи його будинку.

Герой оповідання «Чужий» - випадковий знайомий оповідача. Його історія розгортається ретроспективно, починаючи з замітки в місцевій газеті 1938 року: «Берлінський єврей Генріх Шнайдер засуджений на n’ять років за осквернення арійськоӥ раси» [Бург 2012 : 44]. Через спогади оповідача окреслюється образ головного персонажа. Він - вихідець із незаможної єврейської родини 3 Польщі, що поєднував студіювання германістики в Берлінському університеті й роботу на чавунно-ливарному заводі. Причиною ж його поневірянь стало знайомство й одруження 3 дівчиною, батько якої був палким прихильником ідей націонал-соціалізму й «не міг допустити, щзоб його чистокровна арійська дочка одружилася з проклятим євреєм» [Бург 2012 : 44]. 
Почуття героїв зазнає серйозних випробувань ще в Німеччині, коли Генріх у 1933 році був ув’язнений у концтаборі, але згодом викуплений звідти коханою жінкою. Втеча до Австрії приносить героям хоч i нелегке в побутовому розумінні, але позбавлене переслідувань життя: «Чотири роки ми живемо у Відні, й ніхто нас тут не знає. Ми живемо в одному домі з сусідами, але жодна душа не відає, хто ми $і$ звідки. Чужі. Та й по всьому...» [Бург 2012 : 44]. Так триває до 1938 року, поки в життя героїв не вриваються глобальні політичні події. Назва «Чужий» підкреслює і неофіційний статус, і внутрішній стан як героїв оповідання, так і загалом людей, що опинилися заручниками ситуації, коли незалежна Австрія перетворюється наOstmark Третього Рейху. На противагу персонажеві попереднього твору, Генріх Шнайдер і його дружина $є$ провідниками ідеї незнищенності гуманного начала в людині як вищої моральної чесноти, що має надчасовий, наднаціональний i надконфесійний характер.

Твори розділу «Під небом Буковини» об’єднані, крім топосу, думкою про доречність подвижництва в щоденному житті людини. Зворушливою видається історія прачки Шіфре, сироти, яка овдовіла на наступний день після весілля 3 безрідним Зунею. «Протягом однієї доби довелося їй побувати нареченою, дружиною і молодою вдовою з обручкою з демевого золота» [Бург 2012 : 57], так часовою і подієвоюзгущеністю підкреслює автор драматизм долі Шіфре. Обручка на пальці - це пам’ять про несправджені сподівання i весь скарб жінки, яка «всі изі роки простояла схиленою над величезними ночвами $і$ заробила собі хіба щзо червоні, розпухлі руки, які були схожими на сире м'ясо...» [Бург 2012 : 54]. Автор говорить про традицію єврейської доброчинності, коли громадою справляли весілля сиротам. Саме завдяки такому звичаєві під весільною хупою опинилися Шіфре і Зуня, на таке ж сирітське весілля пізніше жертвує свою обручку Шіфре. Уся широта душі прачки розкривається в лаконічному епізоді на кладовищі: Шіфре приходить до могили чоловіка просити пробачення за обручку, яку вперше за 20 років зняла й віддала чужим людям. Але ii намагання полегшити власну душу обертається проханням за 
чужу їй людину: «Лиш Господь знає, як мені було важко розлучатися з нею [обручкою - Н. Г.]. Але ж вона сирота... Заступися за неї на небесах, Зуня...» [Бург 2012 : 54].

Доробку Й. Бурга властива повторюваність окремих художніх деталей, локусів, персонажів, що поєднує твори малої прози в єдиний художній континуум. Для аналізованої збірки - це передусім локус кафе «Централ», у якому збиралися митці єврейських кварталів Відня, образи діячів єврейської літератури, з яким був знайомий автор і його герої. Укладачем збірки вигідно використана ця особливість манери письма Й. Бурга. Так, у спогадах дитячих літ оповідача спливає образ християнського священника, а розгортання сюжету зустрічаємо вже в оповіданні «Маковей». Семантика назви села Іспас, у якому відбувалися описані події, накладається на історію порятунку євреїв християнським священником. Крізь призму дитячої свідомості, населеної релігійними забобонами й упередженнями, оповідач передає свої перші враження: «У дитинстві, переборюючи в своєму сериі ляк, боячись, не дай Боже, осліпнути, я мчав повз цееркву зі словами молитви на устах. Священника я теж боявся. Якщуо він ішов мені на зустріч, то я кидав через плече пучечок соломи. Чому саме соломи, я й досі не знаю. Чи помічав священник мене, охопленого первісним страхом? Мабуть, щзо так. Бо на його устах з'являлася безпомічна крива усмішка. Пізніше, через багато років, коли я зрозумів, щзо означала ияя усмішка, я, згораючи від сорому, дуже хотів щуе раз зустрітися 3 ним. Я хотів загладити свою вину за отой пучечок соломи й вибачитись перед ним. Але тоді його вже не було на світі» [Бург 2012 : 54]. Та події літа 1941 року змушують оповідача переконатися в тому, що не конфесійна належність робить людину людиною.

Перед читачем постає образ сільського священника в розквіті фізичних i душевних сил, який користується в селі неабияким авторитетом. Але нетиповість його натури для представника духовного стану передається в тексті розрізненими деталями: його очі під густими бровами таять «неспокійний вогонь» [Бург 2012 : 54], ще 3 гімназійних часів він, через своє селянське 
походження, носить зневажливе прізвисько «Мужик», він - онук діда-опришка. Та і його освітні уподобання не свідчать про смиренність: студента духовного навчального закладу вабили соціальні науки й художня, а не релігійна складова Біблії. Автор не ідеалізує образ Маковея, який, за словами оповідача, із байдужістю чи погордою ставився до єврейської частини жителів села. Та загострення суспільної ситуації, культивування нетерпимості на національному і релігійному грунті акумулюють людські якості Маковея й він приходить до однозначного рішення не допустити розбрату й насильства в селі. Внутрішня напруга священника передається через низку містких художніх деталей: «Надія i відчай злились воєдино, і йому здавалось, щзо він тримає у свойх руках обидва кінці життя і смерті...» [Бург 2012 : 67], «Маковей нічого не бачив, нікого не чув $i$, наче божевільний, розгойдував дзвони все сильніше й сильніме, аж поки біля изеркви не зібралося усе село» [Бург 2012 : 69], «його м'який $і$ чистий бас, не дуже сильний від природи, тепер важко гримів, мовби він оголошував комусь війну не на життя, а на смерть...» [Бург 2012 : 70]. П'яні погромники не насмілилися піти проти волі села, що на чолі зі священником постало на захист євреїв, і в Іспасі не пролилося жодної краплини крові. Правда, священик опинився безсилим перед виселенням євреїв до Трансністрії - відданого німцями під тимчасове румунське управління адміністративно-політичного утворення на східних від Дністра землях. За словами Ф. Гейманн, «провінщія існувала лише 2 роки та 7 місяиів, із серпня 1941 р. по березень 1944 р. Але отримала нерадісну долю стати пунктом призначення для євреїв, депортованих з Буковини та Бессарабї, та кладовищеем для двох третин $з$ них» [Гейманн 2010 : 27]. Долі врятованих Маковеєм односельців склалися так, як і решти 110 тисяч євреїв, яких було вигнано до Трансністрії (до речі, там обірвалося життя й матері Й. Бурга), але це не применшує «подвиг совісті» священика.

Цей твір вносить уточнення і в назву всієї збірки. «Пісня над піснями» Й. Бурга, безперечно, апелює до старозавітного контексту, у якому однойменний твір вважається алегорією любові Бога до ізраїльського народу. 
Але в мить перемоги світла на тьмою, що насувалася на Іспас, свою пісню над піснями чує Маковей. Відтак - це мірило, символ не тільки любові Божої до людини, але й любові людей одне до одного.

Завершує розділ оповідання «Цадик», центральним образом-персонажем якого є Азріел - замолоду вправний плотогон, із яким ніхто не міг змагатися в його майстерності, а на старість - убогий лісовий сторож, єдиною зброєю якого була успадкована від предків бартка. Втративши під час епідемії двох доньок, а потому й дружину, він жив самітником i «ніс своє страждання побожно $i$ смиренно» [Бург 2012 : 78]. Автор не вдається в деталізацію життєвих перепитій Азріела, але в момент молитви старого підкреслює його граничну обділеність долею, за яку мало б бути ніяково самому Богові: «Він молився 3 тихою ревністю, в ритмі стародавнього плачу, немовби й справді стояв у той момент перед Богом. Перед тим самими Богом, який, по справедливості, мав би зійти з небес і просити прощуення в Азріела» [Бург 2012 : 78]. Оповідь у творі ведеться від імені партизана, який у роки війни став свідком розправи вже старого й кволого цадика над двома німецькими солдатами. Підкреслюється, що Азріел уперше в житті порушив святість суботи, але відплатив за наругу над своєю гідністю: «Бартка враз ніби розбудила у ньому безстрашність усіх поколінь плотогонів, помножену на страждання і передсмертні крики гнаних $i$ замучених» [Бург 2012 : 83].

Зміна художнього простору в розділі «Російські враження» змушує читача констатувати сумну історичну тяглість проблеми антисемітизму. Твори «Рут», «Два світи» й «Фрески» свідчать про те, що вона не виникла 3 приходом до влади Гітлера, а навпаки, існування побутового антисемітизму робило можливим появу таких державних ідеологій.

Герой оповідання «Рут» $y$ nідсвідомості якого «жили покоління ц̧ькованих, переслідуваних, гнаних» [Бург 2012 : 90], простежує цей історичний шлях нетерпимості й кровопролиття «від інквізицій та погромів до газових камер і крематорїв» [Бург 2012 : 90]. Він у XX столітті зіштовхується 3 поширюваним по радіо марновірством про отруєні євреями колодязі, яке 
виникло ще в далекому XIV столітті під час розповсюдження в Свропі епідемії чуми. Виходить, єдине, що удосконалило людство з тих часів, - засоби передачі інформації. Ім’я біблійної праведниці Рут, яка була чужинкою за народженням, але через глибоку прихильність до родини чоловіка ввійшла до єврейського народу й стала праматір'ю царя Давида, тут є символом подружньої відданості. Дружина героя походить із старовинної шляхетної російської сім’ї, їй не загрожують переслідування на батьківщині, але вона навідріз відмовляється покинути чоловіка: «Куди підеш ти, туди піду й я, а де житимеш ти, там житиму й я. Народ твій буде моӥм народом, а Бог твій - моӥм Богом» [Бург 2012 : 90]. У творі «Два світи» автор підкреслює, що наприкінці 1930-х років «жертовність Ісаака була жорстоко повторена мільйони разів» [Бург 2012 : 90], бо долю євреїв розділили й інші народи Радянського Союзу. Асоціації з біблійним сюжетом жертвопринесення Авраамового сина й долею єврейського народу спливають i в творі «Фрески», герой якого відвідує Ермітаж. У його свідомості на дитячі судження про біблійний сюжет жертвопринесення накладаються враження від побаченого колись настінного розпису церкви i, звісно ж, рембрантівської картини. Часові і просторові рамки твору розсуваються, розщеплюються на пласти, підкреслюючи зв’язок минулого з сучасним. I в очах біблійного Якова на іншому полотні оповідач вбачає неспокій за далеких нащадків: «Можливо, цุi стародавні, налляті споконвічним сумом очі бачили Освєнциим i Треблінку... А, можливо, й відвагу повстанияів Вариавського гетто» [Бург 2012 : 102].

Завершують книгу есеї, об’єднані під заголовком «Постаті». Об’єктом зображення в них стають єврейські ідишомовні письменники Мендель Нейгрешл, Бер Горовіц, Кубі Воль, Елієзер Штейнбарг та Мойше Альтман, долі яких потверджують трагічні віхи історії єврейського народу.

Звичайно, твори Й. Бурга, який присвятив своє життя збереженню рідної мови й культури, просякнуті повагою й любов'ю до спадку предків, але моральна оцінка вчинкам людини в них художньо моделюється незалежно від іiі етнічної чи релігійної приналежності. Як данина людинолюбству автора - 
відзнаки кількох європейських держав за заслуги у розвитку культури i взаєморозуміння між народами.

\section{БІБЛІОГРАФІЯ}

Антошкіна 2010 - Антошкіна Л. Особливості буковинського пограниччя : історія культурного полілогу / Л. Антошкіна, О. Гадинко, Г. Красовська, П. Сигеда, О. Сухомлинов. - Донецьк : ТОВ «Юго-Восток, Лтд», 2010. - 238 с.

Бург 2012 - Бург Й. Пісня над піснями : вибр. проза / упор., передм. та пер. П. Рихла. - Чернівці : Книги-XXI, 2012. - 148 с.

Вишневська 2012 - Вишневська М. «Я - буковинець із голови до п’ят» [Електронний ресурс] / М. Вишневська. - Режим доступу : https://day.kyiv.ua/uk/ article/kultura/ya-bukovinec-iz-golovi-do-pyat

Гейманн 2010 - Гейман Ф. Сврейське життя на Буковині до Голокосту : деякі аспекти // Голокост і сучасність. Студії в Україні і світі. - 2010. № 2 (8). - C. 27-36.

Рихло2012 - Рихло П. Останній лицар ідишу / П. Рихло // Бург Й. Пісня над піснями : вибр. проза / упор., передм. та пер. П. Рихла. - Чернівці : КнигиXXI, 2012. - C. 5-12. 